Niklas Wilhelmsson

\title{
9 Social Capital as a Resource for Political Participa- tion: Finland in a Nordic Comparative Perspective
}

\subsection{Introduction and research questions}

The advanced industrialised democracies have witnessed a decreasing civic involvement among its citizens during recent decades (see Dalton 1996; Dalton et. al. 2002; Wass 2008). ${ }^{1}$ Within a general trend towards decreasing political participation and societal fragmentation, immigration poses an additional challenge by bringing further diversity into European societies (Ireland 1994). With the prospect of an ageing and declining population more immigration to Europe is likely in the coming years. In the mid-2000s, the number of third country nationals residing in the EU-countries amounted to approximately four percent of the total population and immigration has since become the main factor of demographic growth in most European countries (Ahokas 2010).

While immigration and integration in recent years have received frequent attention in the academic literature, the subject has remained largely absent within political science (Saukkonen 2007). Although traditionally integration policies tend to focus on socio-economic topics, governments are increasingly concerned about the importance of the personal dimensions of integration, societal participation and the frequency and intensity of social interactions. ${ }^{2}$ This approach stipulates the need of integration into all aspects of society, including civil society and the political field.

Studies show that migrants are often under-represented in democratic assemblies and hold a marginal position in the public domain (see Myrberg 2004; Vogel and Groupas 2006; Triandafyllidou and Groupas 2007). The participatory parity between migrants and the majority population has been addressed from a number of different angles, some focussing on individual and cultural factors, while others looking at institutional and contextual factors. According to Dahlstedt and Hertzberg (2006:916) there has been a tendency of blaming migrants for sharing such cultural and social features which generally are unfavourable for political participation, while their relatively marginal position in the public domain is related to asymmetric power relations and divergent possibilities to participate and influence the political process. It would thus be more fruitful to address the problem of inequalities in the political domain by focussing on the political and the social context, the institutions and the

1 Electoral participation and other forms of civic engagement have been declining in most Western democracies during the last two decades.

2 This is reflected in the Finnish democracy policy programme (Oikeusministeriön julkaisuja 14/2010). 
opportunity structures available for different social groups (Dahlstedt and Hertzberg 2006:9-16).

In recent years some scholars have used the political opportunity structure approach (POS) for explaining differences concerning political involvement and political action repertoires in a comparative perspective ${ }^{3}$ (Koopmans 2004). This approach focusses on the participatory opportunities that the legal framework and the political system offer. In the academic literature one can find several contextual and institutional explanations for political participation (for an overview see Lane and Ersson 1990; Dalton 1996; Wass and Wilhelmsson 2009). At the macro-level, the institutional context, the legislation, the party system as well as the socioeconomic surrounding affect people's opportunities to participate in politics and in the decision making process (Lane and Ersson 1990). The political inclusion of migrants is additionally affected by the way the government and the legislation take cognisance of migrants and by the way people, political parties and organisations perceive immigration and diversity (Anderson and Cohen 2005).

The integration process is thus not only a relationship between the state and individual migrants, but a partnership between different levels of actors, including civil society associations. Civil society actors can support the integration process if they are proactive in addressing the changing needs, social dynamics and wellbeing of an increasingly diverse population. It is generally believed that social capital, measured as the degree of social involvement and trust, offers many positive features both for individuals and society (Putnam 1993; Putnam 2000). Accordingly, social capital can empower resource weak groups and also serve as a means for more equality in the political domain. Alternatively, access to power can be hampered in the social domain by excluding certain groups from organisational activities and social networks (Fennema and Tillie 1999; Fahmy 2003; Tillie 2004).

It is however still not clear how and if social capital affects political participation. First, it is a contested issue whether social capital actually affects the degree of political participation. Some findings indicate that there is a strong relationship between social capital measured as the degree of organisational participation, trust and political participation (Fennema and Tillie 1999; Tillie 2004), while other findings point towards very modest correlations between these factors (Lundåsen 2004). There may also be contextual differences between countries and local variations, which

3 At the macro-level the effect of the political system for political mobilisation is often studied through the political opportunity structure-approach, which examines how different features of the political system affect political mobilisation. The political opportunity structure approach is not a unified concept or theory, rather, as Tarrow argues, a cluster of variables that describes certain features of the political system which is thought to be relevant for political mobilisation. (Tarrow 1988: 430) The core assumption of the theories is premised on how people act and which strategic choices they make are strongly influenced by the political-institutional context in which they live (Giugni and Passy 2004, 55). 
make the effects of social capital context dependent (Rothstein and Stolle 2003:18). Secondly, there are conflicting views on which types of social connections are most beneficial for individuals and societies. From one perspective ethnic organisations are viewed as important facilitators of the integration process, including political integration - while the opposing view holds that they may block migrants from participating in the majority society. ${ }^{4}$ In the social capital literature this phenomenon is usually addressed through the concepts bridging and bonding social capital (Putnam 2000).

Social capital research has gained quite substantial attention within the Nordic countries. ${ }^{5}$ The Nordic states have traditionally been characterised by strong civil societies, consensus politics and a close relationship between civil society and the government. These countries also traditionally share some other features of social capital, such as a high level of interpersonal trust and a high degree of trust towards the authorities (Rothstein and Stolle 2003). Some researchers are, however, questioning how well the Nordic welfare states are equipped to deal with diversity. Forsander, among others, argues that the strong social capital of the Nordic welfare seems to be exclusionary concerning migrants. In Forsander's words,

\begin{abstract}
Many aspects of the strong social capital hinder immigrant integration into the labour market and therefore into society in general. The homogeneity of the norm base and tight social networks leads to strong in-group loyalty that excludes outsiders who do not-from the perspective of in-group members- share the common norm base. Following the division between bonding and bridging social capital, it seems that the Nordic forms of social capital are more bonding than bridging in nature. (Forsander 2004:1-3)
\end{abstract}

The purpose of this article is twofold; first to test how and if social capital, measured through different forms of organisational participation, affect the political participation of migrants in the Finnish context; and second, to review the Finnish political opportunity structures and the social capital of migrants in Finland from a Nordic comparative perspective. Civil society organisations can both in Finland and in the other Nordic countries be expected to have a central role in the integration process as social connections in these countries mainly are structured based on formal organisation memberships (Siisiäinen and Kankainen 2009). It can also be assumed that migrant organisations and ethnic communities are differently structured in different contexts. The situation in Finland, which is a new country of immigration with a small immigrant population, may be rather different to the one in for example Sweden, which has a long history of immigration and a large immigrant population.

4 The question also indirectly in a broader perspective relates to the debate on whether states should adopt multicultural or assimilationist policies.

5 For example the Academy of Finland has financed a substantial research programme in the field (2000-2007). 
The following research questions will be addressed in this chapter:

- Does social capital (measured as participation in organisations and other forms of social activities) affect the degree of political participation?

- Which form of social involvement is most beneficial for political participation?

- Is social capital in the Nordic countries exclusive (bonding), making societal participation of migrants difficult?

The research questions will be answered through: a survey dataset collected by Statistics Finland among Russian, Estonian, Somali and Vietnamese immigrants living in the Helsinki capital region, Tampere and Turku; ${ }^{6}$ election statistics; the Migrant Integration Policy Index ${ }^{7}$ and the European Social Survey (ESS). ${ }^{8}$

The article begins with a brief overview of the concept of political participation, where the normative importance of an active and engaged citizenry and the problems of political exclusion and marginalisation are discussed. After that, the explanatory factor social capital is discussed, followed by a presentation of the central control variables, which will be used in the multivariate analysis in the empirical portion of

6 The immigrant survey that was conducted by Statistics Finland in 2002 is used as research material. Electoral participation was measured through the following question: Did you vote in the last municipal elections? It is not entirely reliable to measure electoral participation by surveys because of the problem of over-reporting. The reported electoral participation in surveys is generally higher than the actual turnout. This also seems to be the case concerning the immigrant survey. It is difficult to evaluate the reliability of the survey due to a lack of comparable register data. The following question was asked to measure organisational participation: Have you during the last 12 months participated in any of the following activities. 1) sport- and hobby clubs 2) interest organisations 3) political organisations or political parties 4) other organisations (e.g. humanitarian organisations etc. 4) immigrant sportand hobby clubs 5) multicultural meeting places. Social contacts were measured with the following questions: do you have any Finnish friends? How often are you in contact with immigrants from your own ethnic group? How often are you in contact with other immigrants? The sample size of the groups in the survey is in a statistical sense rather small. The samples have been compared to register data from the population register according to age, gender and education categories. The research material seems fairly accurately to represent the compositions of the immigrant groups. There are however statistically significant differences in the response rates between the age groups except for the Somalis. Especially weak response rates are found among over 35 year old Vietnamese immigrants and among the youngest age cohorts of the Estonian and Russian immigrants. Electoral participation was measured through the following question: Did you vote in the last municipal elections?

7 The Migrant Integration Policy Index (MIPEX) measures policies to integrate migrants in $25 \mathrm{EU}$ Member States and 3 non-EU countries. It uses over 100 policy indicators to create a rich, multi-dimensional picture of migrants' opportunities to participate in European societies. MIPEX covers six policy areas which shape a migrant's journey to full citizenship. For a more detailed description on the methodology see: http://www.integrationindex.eu/.

8 The European Social Survey (the ESS) is an academically-driven social survey designed to chart and explain the interaction between Europe's changing institutions and the attitudes, beliefs and behaviour patterns of its diverse populations. Now preparing for its fifth round, the survey covers more than 30 nations and employs the most rigorous methodologies. For a detailed description of the methodology and questioners see: http://www.europeansocialsurvey.org/. 
the study. The last section of the article is devoted to a comparative analysis of the political opportunity structure, social capital and political participation within the Nordic countries.

\subsection{Political participation}

Political participation can take many different forms and is partly dependant on the definition of the concept itself. Political participation is already by definition a contested concept since it is without a universally accepted definition. One often used definition of political participation is the one of Verba, Nie and Kim (1978). They define political participation as 'those legal activities by private citizens that are more or less directly aimed at influencing the selection of governmental personnel and/or the actions they take' (Verba, Nie and Kim 1978:46). This definition may serve its purpose when investigating conventional forms of participation but it is clearly too restrictive when studying political activity from a broader perspective. Not only does it exclude actions which are not directly pointed towards the conventional channels of participation, it also excludes civil disobedience and such new forms of political participation which often target non-state actors in the public, non-profit and private sectors (Norris 2002:193). A broad and more inclusive definition of political participation is for example the one by Barnes et al. (1979:42) where they define political participation as 'all voluntary activities by individual citizens intended to influence directly or indirectly political choices at various levels of the political system.' This definition includes both conventional as well as unconventional forms of political participation. The former entails the participation in the political sphere through direct and often highly institutionalised channels such as voting in elections, candidacy in elections, party membership, campaign activities and petitions. The latter refer to new forms of political actions which often target non-state actors in the public, non-profit and private sectors and different forms of protest behavior, ranging from demonstrations to civil disobedience (Dalton 1996).

Despite the fact that political participation may take many different forms, this article will, due to limitations of space and research materials, mainly focus on electoral participation. ${ }^{9}$ To use electoral participation as an indicator of political participation can also be motivated by the fact that it is the most common form of political participation. It is also known to be strongly connected to more demanding forms of political participation, i.e. those who vote, are usually also taking part in more demanding forms of political activities (see Dalton 1996; Wass and Wilhelmsson 2009).

9 i.e. It forms the dependent variables of the analysis. 


\subsubsection{The importance of political participation and equality}

To enable migrants to feel part of our society, it must be ensured that they have proper tools to participate fully in the society. The political participation of migrants is often addressed through the multi-dimensional concept of political integration, which involves adherence to democratic values, political trust and political participation. In order to be able to talk about political integration, people must at least adhere to the central values of democracy, at least hold some degree of trust towards the political system and the political institutions, and at least to some extent participate in the political process (Tillie 2004:530-531).

One central component of political integration is political participation. Political participation fills many important societal functions and is important both from a normative perspective and from a practical point of view. Robert Dahl argues that some of the most fundamental demands on a well functioning democracy involve political equality and effective citizen participation (Dahl 2000:62-63). This does not however imply that everybody should have to participate in everything all the time. It rather means that the 'decision to participate reflects a political statement instead of being a reflection of a lack of resources or a feeling of powerlessness and political marginalization' (Bengtsson 2004:8).

As political participation forms the input side in the political system, uneven participation patterns may lead to divergent political influence and power configurations. One of the most significant problems relating to divergent participation patterns between different social groups relates to the impact it has on the political agenda (Teixeira 1992). If political participation is considerably lower among some social groups, their interests and desires might to a lesser degree be observed, especially as the political parties often direct their campaigns and efforts towards those groups which are more easily mobilised. A disadvantageous political agenda may in the long run even decrease the interest for involvement among those groups that feel that their voices are not heard and that their interests are not properly taken into account (Wass and Wilhelmsson 2009:19-20).

\subsubsection{Political rights of migrants in the Nordic countries}

A number of European countries have granted basic political rights to migrants, including voting rights in municipal and regional elections (table 1). However, nearly half of the EU Member States countries do not grant voting rights in municipal elections to their resident foreign population. Altogether 12 of the EU-countries strictly deny local enfranchisement. Belgium and Estonia only offer partial political rights for non-citizens. They provide voting rights in municipal elections but deny the possibility of candidacy in elections. Eleven EU-countries offer full local political rights for non-citizens provided that they fulfil the criteria stipulated by 
law. The limitations for obtaining local voting rights vary considerably between member states. ${ }^{10}$ All the Nordic countries provide full political rights at the local level for non-citizens.

The Nordic countries ${ }^{11}$ have had a different path towards providing political rights to non-citizens, which probably both reflects their migration histories as well as the political climates in the countries at the time.

Table 1: Voting rights for third country nationals in EU Member States

\begin{tabular}{|c|c|}
\hline Political rights & EU Member States \\
\hline No local voting rights & $\begin{array}{l}\text { Austria, Cyprus, Czech Republic, France, } \\
\text { Germany, Greece, Hungary, Italy, Latvia, } \\
\text { Lithuania, Luxembourg, Poland }\end{array}$ \\
\hline $\begin{array}{l}\text { Local voting rights but not the right to stand as a } \\
\text { candidate in elections }\end{array}$ & Belgium, Estonia \\
\hline $\begin{array}{l}\text { Full voting rights conditional upon fulfilment of } \\
\text { some requirements }\end{array}$ & $\begin{array}{l}\text { Denmark, Finland, Ireland, the Netherlands, } \\
\text { Malta, Portugal, Slovakia, Slovenia, Spain, } \\
\text { Sweden, UK }\end{array}$ \\
\hline
\end{tabular}

Source: Triandafyllidou and Groupas (2007)

In 1975, Sweden was the first country in the world to introduce voting rights in local elections to foreign citizens. In Denmark and Norway migrants received voting rights in the 1980s. In Finland, residents of other Nordic countries gained voting rights in 1975 but it took until 1992 before other foreigners received similar rights. In Finland laws governing the political organisation and the political participation of foreigners were restrictive before the 1990s.

In the Nordic countries a reform of election laws was seen as a necessary step towards including migrants in politics. It was believed that immigrants as any other citizens would have a natural interest to be involved in the decision making process, because they are directly affected by the political decisions that are made at the municipal level. It was also believed that allowing migrants to participate in the political process would more strongly bind them to society (Hammar 1979; Lepola 2004:278-282).

10 The time limit of residence and residence status for obtaining voting rights vary quite considerably between different EU member states. For an overview see: www.politis.org; Triandafyllidou and Groupas (2007).

11 The Nordic countries can be characterised as a municipal state with fairly extensive rules for municipal self- governance. Municipalities are in charge of arranging many of the welfare policies, housing, education and healthcare. Many of these important decisions are made at the local level, making local elections important. 


\subsection{The explanatory variable: social capital}

The civil society has been at the centre of democratic theory ever since Alexis de Tocqueville's study of 19th century America revealed that democracy works better and citizens are more engaged when people learn to cooperate within the civil society (de Toqueville 2000). During the decades after World War II civil society fell into the background of academic debates. The discussion about the importance of the civil society for democratic performance was revitalised through social capital theory. The concept was introduced by Hanifa at the beginning of the 20th century but gained larger acknowledgement especially through Robert Putnam (Infed encyclopedia 2005).

The concept of social capital has been highly contested in the academic literature. ${ }^{12}$ Different definitions have resulted in divergent understandings of the concept. In Putnam's view social capital refers to social networks, reciprocity norms, mutual cooperation and trust (Putnam 1993). Social capital, in Putnam's meaning, is of utmost importance in a multicultural society for building trust between groups coming from different cultures. Intercultural dialogue and bridging social connections are needed in order to build social capital between different groups (Niemelä 2007:86-87). Civic activities are important in developing reciprocity and mutual norms, as civil society organisations form a protected environment where people can learn to cooperate, trust each other and learn necessary civic skills (Fennema and Tillie 2001:203-204).

The role of social capital for the inclusion of migrants in the political domain of the receiving society has received increasing attention since the frequently cited article by Fennema and Tillie (1999) was published. According to the authors (1999), social capital - measured as the degree of 'ethnic civic community' - was the most important factor explaining the political mobilisation of immigrant groups in the Netherlands. Their hypothesis has been tested in a number of studies since, but the results have been ambiguous. Contradictory results have been found, particularly concerning different forms of social organisations and the impact they have on political participation and political trust in society (see Uslaner and Conley 2003; Berger et. al. 2004; Togeby 2004).

\subsubsection{Bridging and bonding social capital}

The role of social capital for a well functioning society has frequently been discussed since Putnam's seminal study of Italy (Putnam 1993). Putnam's work was originally criticised for being too optimistic and ignoring the negative aspects of civil society organisations. As a reaction to the critique, Putnam introduced the concepts bridging

12 For a discussion see Rothstein and Stolle 2003. 
and bonding social capital. Bridging social capital refers to social connections which are inclusive and connects different groups. Bonding social capital is on the other hand exclusive and tends to strengthen closed identities. A bridging social capital has often, from a societal perspective, been viewed as more beneficial because it connects people and creates unity. A bonding social capital is on the other hand considered exclusive and tends to strengthen closed group identities. It may however form an asset as it can maintain mutuality and solidarity within a specific group (Putnam 2000:22-23).

One of the central questions in the debate concerning bridging and boding social capital is whether states should adopt assimilationist or multicultural policies. Borevi notes that based on Putnam's notion it seems to be more beneficial for states to favour assimilationist policies because it creates a bridging social capital, which favours the integration of migrants. On the other hand it is not in accordance with the normative basis of the liberal state to try to enforce migrants to abandon their own cultural traditions in favour of integration. At the same time it violates the principle of political equality by imposing a certain identity on persons in order to be included in the political community (Borevi 2004:34-35). As was explained in the introductory part of this chapter, the Nordic welfare model has been criticised for creating a bonding social capital, which makes it difficult for migrants to get fully involved within the Nordic societies. I will come back to this issue in the empirical part of the study.

Another question concerning bridging and bonding social capital deals with the role of immigrant organisations (Berger et. al. 2004; Togeby 2004). According to what sometimes is called the assimilationist view, social organisations are important resources for migrants as long as the activities occur within the framework of the society in general. Immigrant organisations on the other hand, have a tendency to isolate migrants from the rest of society, as strong social networks within a closed community isolate outsiders and inhibit members from participating in social networks outside it (Uslaner and Conley 2003). Meanwhile it is argued that they may lead to an increasing fragmentation of the society and being unbeneficial for the integration process. Concerning political participation, the assumption is that members of strong social circles inhibit a formation of common political goals and interests between migrants and the majority population. Meanwhile, members of closed migrant communities have less access to such organisations where the political learning process takes place and thus also get exposed to a lesser extent to political information and recruitment attempts, than those that are engaged in 'bridging networks' (Teorell 2003:51-52). They consequently have less opportunity to attain the democratic skills that are needed for political participation.

The opposing view maintains that immigrant organisations may function as a gateway into society in general (Togeby 2004) as strong social ties within a specific group brings about a strong confidence in one's own identity, which at the same time develops respect and a will to co-operate with others (Valtonen 1999:475). Immigrant organisations can also provide information, advice and assistance for immigrants 
in their native languages and act as a contact channel to the majority population (Mikkelsen 2003:16) forming the basis for what Togeby calls double integration - where immigrants interact both within the ethnic community as well as within society in general. This also provides the basis for an inclusion into the political domain (Togeby 1999:671). Borevi also notes that vertical relationships within a closed community may equally represent a resource for political participation because they form a social base for participation for the group members (Borevi 2004).

\subsubsection{Hypotheses}

Based on the theoretical discussion in the previous chapters, it is possible to formulate four research hypotheses which will be tested by using the research material described in the introductory section of the study. The following hypotheses will be tested:

1. Social capital, operationalised as organisational participation, constitutes a resource that enhances electoral participation, i.e. electoral participation is expected to be higher amongst immigrants participating in organisational activities.

2. Organisational participation forms an asset for electoral participation irrespective of the type of activity (ethnic versus non-ethnic).

3. The range (the share number) of organisational participation is a more decisive feature for electoral participation than the type of activity.

4. Social capital is bonding in the Nordic states due to the homogeneity of the norm base and tight social networks which form an obstacle for migrants societal participation.

\subsection{Control variables}

In order to confirm the validity of the hypotheses that were posed, each hypothesis should hold even when other variables affecting electoral participation are taken into account in the analysis. Socio-demographic and human capital features of the electorate have usually formed the foundation for explaining differences in political behaviour (Holmberg 1981:16-17). Research on the social characteristics of voters has been common in electoral studies since they are easy to measure and they stand behind many variables that are more difficult to measure (Milbrath and Goel 1977:86). At the individual level many studies have shown that the socio-demographic characteristics of the electorate are significant explanatory factors for electoral behaviour. Differences in electoral participation have, amongst other factors, been explained by differences in age, gender, educational attainment, occupation and marital status. General patterns that have been found include that younger people participate to a lesser extent than middle aged and older ones, that married people are 
more active than singles and that highly educated and those who have a higher level of income participate to a higher degree than other groups in society. Traditionally, men have participated more actively than women, but over the last two decades this pattern has changed in favour of women in many developed democracies (Verba and Nie 1972; Millbrath and Goel 1977; Van der Eijk 2000).

Some studies have shown that the lower electoral participation amongst migrants partly reflects their lower human capital (Hammar 1979; Bäck and Soininen 1996). Studies dealing with the societal participation of migrants have also shown that there is a relationship between language proficiency and political participation. It is argued that language proficiency makes it easier to follow politics and election campaigns which raises interest towards politics and increases electoral participation (Jacobs and Tillie 2004:422).

Citizenship has also been viewed as an important prerequisite for political participation because it provides people with the right to vote in 'first-order' elections (parliamentary and presidential elections), which strengthens the democratic learning process and increases interest towards politics. Citizenship also makes living in the country of immigration become permanent, which increases engagement within all sectors of society (Togeby 2004:521). With the above stated motivations, gender, age, marital status, educational attainment and labour market position have been chosen as control variables in the analysis. The impact of citizenship and language skills will also be taken into account in the analysis. Before analysing the relationship between organisational participation and electoral participation a brief presentation on the electoral turnout rates and organisational participation of migrants in Finland will be made.

\subsection{Political participation among migrants in Finland}

The political participation and representation of foreigners in Finland has so far been fairly modest and it has mostly been concentrated within specific groups (Lepola 2004:8). The political parties have only recently reacted to the growing number of people of foreign descent having voting rights. Electoral participation among foreign citizens has remained at a low level ever since 1992, when foreigners were first granted voting rights in municipal elections (see table 2).

The fairly steep decline in electoral participation that occurred between 1992 and 1996 is most likely related to a revision of the municipal law, which took place in 1995. This provided a much larger number of migrants with voting rights, and reduced the time limit for obtaining voting rights. Electoral turnout since the 1996 municipal elections among foreign citizens has been fairly stable. The mean turnout rate among foreign citizens has been between fifteen and twenty percent, compared to the total average turnout rate in municipal elections, which has ranged between 56 per cent 
and 71 per cent. ${ }^{13}$ The turnout rate among EU-citizens and citizens of Norway and Iceland has been somewhat higher than amongst the rest of the foreign population. There are also some smaller regional variations in electoral turnout between foreign citizens living in the periphery and those living in the cities. ${ }^{14}$ In some locations, such as Pirkanmaa in Eastern Finland and Lapland in the North, electoral turnout amongst foreign citizens has been higher than in other regions, which at least partly reflects differences in the composition of the migrants groups living in these areas, as well as favourable candidate nominations (Wilhelmsson 2008). The number of candidates with migrant backgrounds has been growing since the 1990s, but is still lower than the number of foreigners holding voting rights would indicate. In the last municipal election in 2008, 3.2 per cent of the electorate had a mother tongue other than Finnish, Swedish or Sámi, while only 1.5 per cent of the candidates and 0.3 per cent of those who where elected had a different mother tongue than the above mentioned. Altogether, 34 persons with foreign background, of which 13 where women, were elected in the 2008 municipal elections (Association of Finnish Local and Regional Authorities 2010).

Table 2: Electoral participation

\begin{tabular}{lllll}
\hline $\begin{array}{l}\text { Electoral } \\
\text { turnout (\%) }\end{array}$ & Total & $\begin{array}{l}\text { Turnout foreign } \\
\text { citizens }\end{array}$ & $\begin{array}{l}\text { EU-citizens, citizens of } \\
\text { Iceland and Norway }\end{array}$ & Other foreign citizens \\
\hline 2008 & 61.3 & 19.6 & 20.8 & 16.6 \\
2004 & 58.6 & 15.3 & 17.9 & 13.5 \\
2000 & 55.9 & 20.8 & 30.4 & 17.7 \\
1996 & 61.3 & 20.7 & 32.0 & 16.7 \\
1992 & 70.9 & 40.5 & 50.1 & 34.4 \\
\hline
\end{tabular}

Source: Statistics Finland

\subsubsection{Organisational participation among immigrants in Finland}

Finland has sometimes been characterised as a country of organisations. Most Finnish people belong to one or several civil society organisations. Even if some quite fundamental changes have occurred in Finnish civil society in recent decades, the organisations sector is still vibrant and a fundamental part of how social activities are arranged in Finland (Siisiäinen and Kankainen 2009).

13 Immigrant groups are by no means homogeneous. Migrants should be considered, rather, as individuals or members of specific sub-categories defined by national or ethnic origin, religion, gender, age or reason for their arrival. It is however impossible to single out persons from the electoral register based on other features than nationality. Migrants who have received Finnish citizenship do not appear on the register.

14 Most of the foreigners enjoying voting rights live in the capital region and in other larger cities. 
Immigrant organisations in Finland are, on the other hand, a fairly recent phenomenon due to the country's short migration history. The first immigrant organisations were established in the 1990s and the number of organisations has rapidly increased since then (Saksela 2003). Overall the possibilities for ethnic integration into organisations are relatively scarce in the Finnish context due to the relatively low number of immigrants living in the country and the relatively heterogeneous feature of the migrant population (Forsander 2004:190). In the immigrant survey that was conducted by Statistics Finland in 2002 migrants were asked about their participation in organisational activities. The results are presented in table 3.

Table 3: Organisational participation among immigrants in Finland

\begin{tabular}{llllll}
\hline Type of organisation / activity (\%) & Estonian & Russian & Somali & \multicolumn{2}{l}{ Vietnamese Total } \\
\hline Residence events & 50 & 51 & 48 & 40 & 48 \\
& $\mathrm{~N}=312$ & $\mathrm{~N}=522$ & $\mathrm{~N}=324$ & $\mathrm{~N}=119$ & $\mathrm{~N}=1351$ \\
\hline Sports and leisure organisations & 31 & 28 & 20 & 12 & 25 \\
& $\mathrm{~N}=305$ & $\mathrm{~N}=513$ & $\mathrm{~N}=323$ & $\mathrm{~N}=193$ & $\mathrm{~N}=1334$ \\
\hline Voluntary organisations & 6 & 8 & 7 & 8 & 7 \\
\hline Political organisations & $\mathrm{N}=304$ & $\mathrm{~N}=324$ & $\mathrm{~N}=324$ & $\mathrm{~N}=193$ & $\mathrm{~N}=1320$ \\
\hline Interest organisations & 0,3 & 2,4 & 2,5 & 1 & 1,7 \\
(labour unions etc.) & $\mathrm{N}=297$ & $\mathrm{~N}=334$ & $\mathrm{~N}=324$ & $\mathrm{~N}=193$ & $\mathrm{~N}=1148$ \\
\hline Immigrant leisure and sports & 12 & 6 & 3 & 9 & 6 \\
organisations & $\mathrm{N}=304$ & $\mathrm{~N}=512$ & $\mathrm{~N}=324$ & $\mathrm{~N}=193$ & $\mathrm{~N}=1337$ \\
\hline Range of activities (\%) & 10 & 36 & 6 & 17 \\
\hline No participation & & $\mathrm{N}=518$ & $\mathrm{~N}=324$ & $\mathrm{~N}=193$ & $\mathrm{~N}=1344$ \\
\hline Participates in 1 activity & 0.6 & 0.6 & 0.7 & 0.3 & 0.5 \\
\hline Participates in 2 activities & 312 & 521 & 324 & 193 & 1355 \\
\hline Participates in 3 or more activities & 0 & 3 & & & 1 \\
\hline Mean & 54 & 56 & 54 & 78 & 58 \\
\hline $\mathrm{N}$ & & & 29 & 17 & 30 \\
\hline
\end{tabular}

(Source: Statistics Finland) 
As the figures of table 3 reveal, almost half of the migrants participate in residence activities and a third participate in some forms of organised leisure and sports activities. ${ }^{15}$ Almost one in ten participate in some form of voluntary organisations; a type of organisational activity, which during recent years has been growing the most among native Finns (Siisiäinen and Kankainen 2009). Differences in participation patterns between the groups in the research sample are relatively small, except for leisure and sports activities in which Russian and Estonian migrants are most actively engaged, while participation overall is more modest especially among Vietnamese migrants. Participation in political organisations is on the other hand rare for all of the groups, which probably reflects the fact that political parties in Finland have only recently directed special efforts to recruit migrants as party members or nominated candidates with migrant backgrounds (see Weide 2008). Meanwhile there has in general been a steep decline of overall party memberships in Finland during the last two decades (Mickelsson 2009).

We also find some variations in the participation patterns in labour market organisations, which at least partly may reflect the labour market positions of the respective groups. Almost one fifth of the respondents in the immigrant survey reported that they participate in the activities of immigrant organisations. Somali migrants are most actively involved in the activities of the immigrant organisations. The involvement among Russian and Vietnamese immigrants is considerably lower. Estonian migrants participate the least in the activities of the immigrant organisations, which probably reflects the fact that Estonian immigrants to a greater extent are involved within organisations in the majority society. Overall, roughly half of the migrants do not participate in any organisation activities (organised activities), while the other half participates in one to two activities. The greatest group differences are to be found between Vietnamese migrants and the rest of the groups in the sample.

\subsubsection{An analysis of the link between organisational participation and electoral participation among migrants in Finland}

The link between organisational involvement and electoral participation is tested in the regression analysis in table 4. The regression model is based on the analytical model presented in the theoretical part of the article. In the first regression model the range of organisational participation (participation in organised activities) has been entered into a logistic regression analysis together with the control variables, presented in paragraph 4 (control variables) Electoral participation forms the

15 This finding is in line with previous studies (see Harinen 2005). 
dependent variable of the analysis. ${ }^{16}$ In the second regression model different forms of organisational memberships (ethnic versus non-ethnic) have been entered into the analysis together with the same variables as in regression model one.

The results essentially confirm the hypothesis that was posed. Organisational involvement comes out as a fairly strong predictor of electoral participation, even while controlling for other social differences, i.e. the more actively one participates in organisational activities the higher the odds are for electoral participation. It thus appears that organisational involvement would form a pathway towards increasing political involvement. Based on earlier research one may also assume that if organisational involvement in general is beneficial for electoral participation, it should be even more beneficial for participation in more demanding forms of political activity (Vogel and Groupas 2006:14). One problem remains with the conclusion: is increasing political participation actually an effect of social involvement or is it merely just a reflection of overall active citizens? This question remains largely unanswered within the literature, even if there is quite profound theoretical evidence to support the argument in our case (see Putnam 1993; Fennema and Tillie 1999; Rothstein and Stolle 2003).

Secondly, I find no evidence suggesting that involvement in immigrant organisations would isolate migrants from the majority society. On the contrary, participation in immigrant organisations positively relates to electoral participation, even if the relationship is more modest than among other types of organisational activities. This may reflect the largely non-political character of immigrant organisations (see Ålund and Shierup 1991:120-121 for an overview of immigrant organisations in Sweden; for Finland see Saksela 2003) or limitations concerning the research material. ${ }^{17}$ Another feature that seems to support the case is that most of the migrants participating in immigrant organisations also participate in some nonethnic organisational activities, which indicates that they function as a gateway into civil society in general, rather than separating migrants from the majority population.

Aside from organisational involvement, citizenship comes out as the most decisive predictor of electoral participation. Citizenship provides people with full political rights and makes the state of residence permanent, which according to earlier studies significantly increases the odds for participation in all types of societal activities (see Togeby 2004). This also raises a question on how citizenship policies may act as a

16 A logistic regression model has been used as the dependent variable is dichotomous (voted / did not vote). The variables have been entered by the forced entry method, which generally is the most suitable and most widely used method of entering variables into a regression analysis in social sciences. The measure in the right column of the table signifies the B coefficient in the regression model, which tells us how strong the influence of the variable is. The stars signify the level of significance, i.e. if the variables can statistically be confirmed. This implies that there is a 90 per cent or greater chance that there is a relationship between the variables.

17 Limitations may relate to how the question was phrased in the survey and the fact that many migrants left the question unanswered. 
barrier for political integration and participation. In Finland citizenship policies are rather strict from a comparative perspective, which may have a negative impact on the political integration of migrants, as it may take almost a decade of permanent residence in the country before acquiring full civic rights.

Table 4: Social capital and electoral participation

\begin{tabular}{lll}
\hline Variables & Model 1 & Model 2 \\
& B & B \\
\hline Gender & $0.478^{\star \star \star}$ & $0.449^{\star \star \star}$ \\
Marital status & 0.210 & 0.191 \\
Age 26-35 & -0.165 & -0.179 \\
Age 36-45 & 0.124 & 0.087 \\
Age 46-55 & 0.358 & 0.332 \\
Education (in country of origin) & $0.956^{\star \star \star}$ & $0.893^{\star \star \star}$ \\
Education (in Finland) & $0.064^{\star \star \star}$ & $0.066^{\star \star \star}$ \\
Labour market position & 0.210 & 0.214 \\
Language proficiency & 0.123 & 0.156 \\
Citizenship & $1.112^{\star \star \star}$ & $1.107^{\star \star \star}$ \\
Time of residence in Finland & $-0.403^{\star \star \star}$ & $-0.400^{\star \star \star}$ \\
Ethnic group: Estonian & -0.309 & $-0.393^{\star}$ \\
Ethnic group: Somali & 0.207 & 0.252 \\
Ethnic group: Vietnamese & -0.370 & -0.396 \\
Participates in 1 organisation & $0.838^{\star \star \star}$ & - \\
Participates in 2 organisations & $1.339^{\star \star \star}$ & - \\
Participates in 3 or more organisations & $1.716^{\star \star \star}$ & - \\
Organisational participation (ethnic) & - & $0.371^{\star \star}$ \\
Organisational participation (non-ethnic) & - & $0.175^{\star}$ \\
N & 1087 & 1076 \\
-2 Log lik. ho. & 1172,443 & 1160,857 \\
Nagelkerke R & 0.27 & 0.27 \\
\hline & & \\
\hline & & \\
\hline
\end{tabular}

Commentary: Regression analysis (binary logistic). Dependent variable: $0=\operatorname{did}$ not vote, $1=$ voted. Independent variables: Gender: $0=$ female, $1=$ male. Marital status: $0=$ unmarried, divorced, widow, $1=$ married, cohabiting. Age: $18-24$ coded as reference category, other age variables coded as dummy variables. Education in country of origin: continuous variable ranging from $0-23$ years of education. Education in Finland: $0=$ no formal education, $1=$ ammattitkulutus or university degree in Finland. Language proficiency: 0 = weak Finnish/Swedish skills, $1=$ good or sufficient skills in Finnish. Citizenship: $0=$ foreign citizenship, $1=$ Finnish citizenship. Time of residence in Finland: continuous variable ranging from 0-20. Ethnic groups: Russians coded at reference category, other ethnic groups coded as dummy variables. Organisational participation (range): no organisational participation coded as reference category, the rest coded as dummies. Organisational participation (ethnic): $0=$ no participation, $1=$ participates. Non-ethnic organisational participation $: 0=$ no participation, $1=$ participates. Notation $: p<0.01={ }^{* \star *}, p<0.05={ }^{* *}, p<0.1=*$. 
Besides citizenship, time of residence in Finland, gender and education are the other variables which show a statistically significant relationship with electoral participation. It is not highly surprising that the time of residence is connected to the level of political participation as it takes time to get acquainted with society and the political system, which makes it more likely for those who have stayed longer in the country to participate in politics. We also know from earlier studies that people who are frequently moving are often less engaged in their local communities. Gender differences may on the other hand reflect the fact that politics in some cultures are male dominated, making the political integration of women an issue one should direct special attention to. Education, on the other hand, is one of the so called 'usual suspects' while studying political participation, as it strengthens the skills and abilities to follow and engage in political activities. One could thus raise the question, of whether education in societal matters should be more strongly incorporated into the agenda of the integration courses that are offered to immigrants.

\subsection{Civic rights, electoral participation and organisational activity among migrants in a Nordic comparative perspective}

In the previous sections we have discovered that the electoral participation of migrants in Finland at the individual level is connected to organisational involvement, formal citizenship and other social resources. In order to put Finland into a comparative perspective and discern how organisational involvement and other systemic features affect political participation, the next section includes a comparative analysis of the Nordic countries. The Nordic countries are often used in comparative analyses, as the countries share many historical and systemic features. Due to many similarities, the Nordic countries also form a useful analytical framework when considering migrant integration, but they still have very distinctive features, concerning their migration history, the size of the migrant population as well as integration policies.

The Nordic countries differ quite substantially concerning migration patterns and the number of migrants living in the countries. Migration to Sweden and Denmark started in the 1960s and the countries have fairly large migrant populations. Migration to Norway started roughly a decade later than in the two previously mentioned countries. Finland forms a deviant case as the country, during the 1960s and 1970s, was notably characterised with outwards migration, to, among other countries, Sweden. Immigration to Finland started late and it was not until the 1990s that Finland received a higher number of migrants, and in 2010 the migrant population was still among the smallest in Europe. The Nordic countries also vary concerning both the composition of the migrant groups and the main reasons for migrating to the country (see Triandafyllidou and Groupas 2007).

In all the Nordic countries the electoral participation of migrants has been considerably lower than among the general population. Even though electoral 
participation has in general been declining in all the Nordic countries during the last decade, Denmark, Sweden and Norway still belong to the group of countries with high electoral participation, while Finland has dropped below the European average (Wass and Wilhelmsson 2009:34). Among migrants, electoral participation has generally decreased gradually as voting rights have become more inclusive. There are, however, considerable variations in turnout rates between different migrant groups and different local contexts, which is a question for further analysis in forthcoming studies. While comparing electoral participation amongst migrants in the Nordic countries, turnout rates have been highest in Denmark followed by Norway. In Sweden electoral participation amongst migrants has been lower and declining ever since the introduction of voting rights for foreign citizens in 1975. Finland forms the extreme case as electoral participation amongst migrants is considerably lower than in the other Nordic countries.

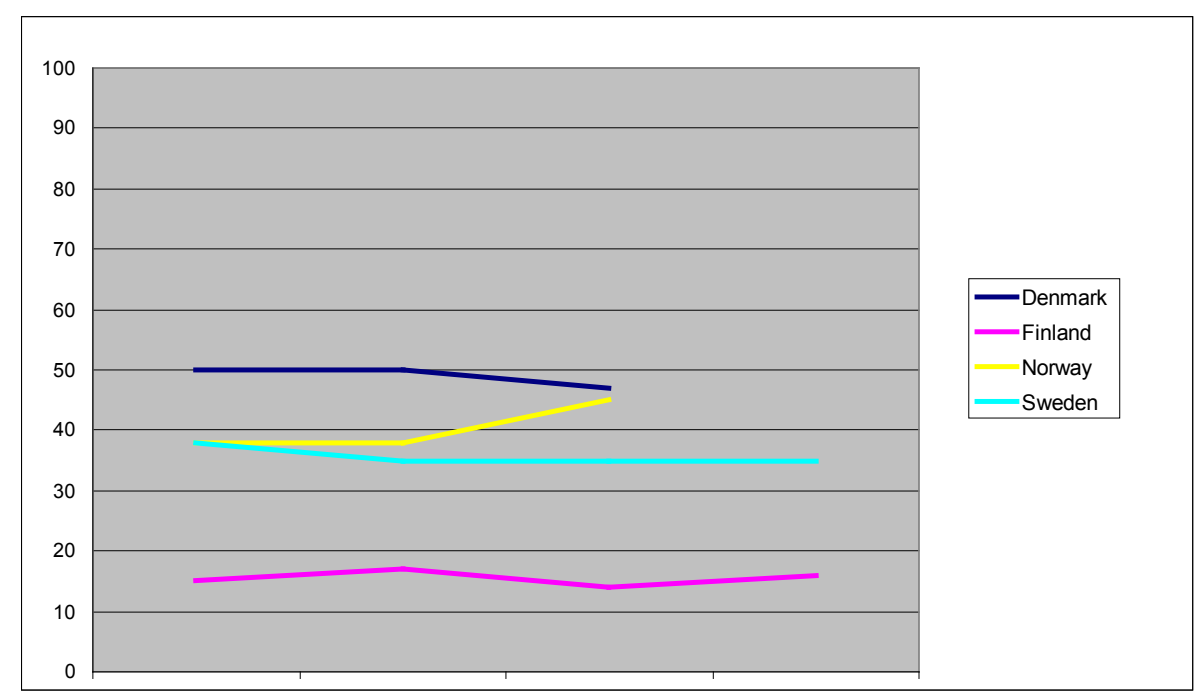

Figure 1: Electoral turnout among migrants in municipal elections in the Nordic countries ${ }^{18}$ Sources: Denmark; Togeby (1999); Spies (2010), Finland; Statistics Finland, Norway; Melve (2003); Sweden; SEB, Benito (2005).

In the following discussion, some features of the political opportunity structures of the Nordic countries will be evaluated based on measurements from the Migration

18 Commentary to the table: For Denmark there are no available figures for 2005 and 2009 (Spies 2010, 133); for Norway the most recent figures found by the author of this article is from 2003. 
Integration Policy Index. The Migrant Integration Policy Index (MIPEX) measures policies to integrate migrants in 25 EU Member States and 3 non-EU countries. It uses over 100 policy indicators to create a rich, multi-dimensional picture of migrants' opportunities to participate in European societies. MIPEX covers six policy areas which shape a migrant's journey to full citizenship. Koopmans argues that the political opportunity structures either may stimulate or constrain and channel the levels of political involvement among migrants and ethnic minorities (Koopmans 2004:449).

Table 5 highlights some policy features of the Nordic countries that are evaluated based on the Migration Integration Policy Index. According to the MIPEX index, Sweden has the most inclusive integration policies among all European countries as well as the most extensive political rights for migrants. Norway and Finland also score fairly well on both of the above mentioned dimensions while Denmark only scores close the EU average on the index. Overall, each of the Nordic countries, except for Denmark with some reservations, score very well on the index.

Table 5: Political rights according to the Migration Integration Policy Index

\begin{tabular}{lllllll}
\hline & $\begin{array}{l}\text { Long term } \\
\text { residence }\end{array}$ & $\begin{array}{l}\text { Family } \\
\text { reunification }\end{array}$ & $\begin{array}{l}\text { Rights } \\
\text { to citizenship }\end{array}$ & $\begin{array}{l}\text { Political } \\
\text { rights }\end{array}$ & $\begin{array}{l}\text { Anti-discrimination } \\
\text { measures }\end{array}$ & $\begin{array}{l}\text { Labour } \\
\text { market }\end{array}$ \\
\hline Denmark & 67 & 36 & 33 & 55 & 33 & 40 \\
Finland & 65 & 68 & 44 & 81 & 75 & 70 \\
Norway & 72 & 66 & 39 & 86 & 54 & 70 \\
Sweden & 76 & 92 & 71 & 93 & 94 & 100 \\
EU-15 & 61 & 59 & 48 & 60 & 66 & 64 \\
EU-10 & 57 & 55 & 37 & 20 & 48 & 45 \\
EU-25 & 59 & 57 & 49 & 43 & 58 & 56 \\
\hline
\end{tabular}

When comparing levels of inclusivity of political rights and integration policies, with political participation in the Nordic countries, no clear pattern emerges. Even though Denmark scores lowest among the Nordic countries on the MIPEX index, electoral participation among migrants is significantly higher in Denmark than in the other Nordic countries. Based on these figures it is not possible to draw any far reaching conclusions on the impact of integration related policies on democratic participation. There may be other systemic factors such as how policies are implemented, which in practice has a much greater impact on the political and social involvement of migrants, as indicated in the discussion surrounding table 6 .

In table 6 the organisational involvement of migrants in the Nordic countries are examined based on the European Social Survey (ESS) to study whether social capital 
- measured as the degree of participation in organisations can be viewed as bonding and exclusive, making it hard for migrants in the Nordic countries to participate in organisations.

Table 6: Organisational memberships and organisational participation among migrants in the European countries (ESS)

\begin{tabular}{lllll}
\hline & Membership (\%) & Membership (\%) & Participation (\%) & Participation (\%) \\
\hline & Native & Migrant & Native & Migrant \\
Sweden & 2.5 & 1.9 & 0.9 & 0.6 \\
Denmark & 2.5 & 1.7 & 0.9 & 0.7 \\
Norway & 2.2 & 1.7 & 0.8 & 0.5 \\
Netherlands & 2.2 & 1.7 & 0.8 & 0.5 \\
Austria & 2.2 & 1.5 & 0.8 & 0.8 \\
Belgium & 1.6 & 1.2 & 1 & 0.8 \\
Ireland & 1.6 & 1.7 & 0.7 & 1 \\
Finland & 1.6 & 1.1 & 0.6 & 0.5 \\
Great Britain & 1.6 & 1.6 & 0.9 & 1.3 \\
Germany & 1.5 & 1 & 0.7 & 0.5 \\
France & 1 & 0.8 & 0.8 & 0.7 \\
Spain & 0.7 & 0.4 & 0.4 & 0.2 \\
Portugal & 0.5 & 0.4 & 0.3 & 0.3 \\
Greece & 0.5 & 0.2 & 0.2 & 0.1 \\
\hline
\end{tabular}

Commentary: The table is based on data material from the European Social Survey (ESS1-2002). The following questions were asked: Are you a member of any of the following organisations? Have you during the last year participated in any of the following organisation activities? 12 different categories of organisations were given in the questionnaire.

Based on data from the European Social Survey, we can discern that people of the Nordic countries are among the most active organisation members and they also actively participate in organisation activities, which is hardly surprising considering the traditionally important role of civil society within the Nordic countries (see Borg 2005; Siisiäinen and Kankainen 2009). In Finland, involvement is somewhat lower both among migrants and among the general population than in the other Nordic countries. Also in the other Nordic countries, migrants participate somewhat less in civil society organisations than the general population. The figures do not provide any strong support for the hypothesis that social capital in the Nordic welfare states would be bonding, making it especially hard for migrants to participate in organised 
activities as Forsander (2004) argues. Based on the data, it seems rather that migrants living in the Nordic countries, would from a comparative perspective, be fairly actively involved in organisational activities compared to migrants in other European countries.

\subsection{Discussion}

Political rights certainly form the basic prerequisites for political participation, but it seems that political mobilisation requires both favourable institutional structures and policies, combined with efforts of political parties and civil society organisations and other relevant actors. According to the MIPEX index the Nordic countries seem to have fairly open and good integration and citizenship policies, except with some reservations for Denmark. All the Nordic countries also offer full political rights for non-citizens at the local level. Even though legislation and policies are inclusive, there is still a risk of failure in the implementation, concerning which there is limited knowledge and data.

Social capital in the Nordic welfare states has been claimed to be bonding and exclusive due to the homogeneity of the norm base and tight social networks, which leads to strong in-group loyalty (Forsander 2004). Concerning involvement in organisational activities, our data does not support this hypothesis. There is also limited knowledge of how divergent the participation patterns between different migrant groups are. There is also some evidence of difficulties that migrants have experienced concerning participation in civil society organisations. In all the Nordic countries there seem to exist some barriers to participation, such as language skills and experiences of racism or discrimination (see for example Harinen 2005). In Finland, immigrant organisations are a fairly recent phenomenon, while they have a much longer history in the other Nordic countries. Migrants also seem to have more difficulties associated with organising internally in Finland than in the other Nordic countries, due to the fact that immigrant groups in Finland are small and heterogeneous.

The relationship between organisational participation and political participation found at the individual level is less clear on the macro-level. In Denmark some immigrant organisations have had political issues on their agendas and have enjoyed success in mobilising migrants into political participation (see Melve 2003). In Sweden and Finland immigrant organisations have mostly been non-political and migrants have mostly participated in organisations without political goals, which may affect the degree to which these organisations mobilise immigrants into other forms of societal activities.

Aside from government policies, there are several systemic and contextual factors affecting the political mobilisation of migrants. Earlier studies have shown that proportional systems that offer the possibility to vote directly for a candidate 
tend to be more favourable for migrant mobilisation than majority systems with closed candidate lists (see Togeby 2008). There are also numerous contextual factors affecting the political mobilisation. According to Saukkonen (2007:284-88) minorities have usually managed to mobilise politically in circumstances where the group has gained significant political or economical power, where political organisations or parties have managed to mobilise the minority, where the political system is open for new claims or where a minority feels its position is significantly threatened.

In Denmark, electoral participation has been considerably higher than in the other Nordic countries, although the Danish integration regime has been viewed as less inclusive than in the other Nordic countries. Lise Togeby, who has compared electoral turnout among migrants living in Denmark and Sweden, claims that the Danish individual centred electoral system, with a number of migrant candidates connected to fairly well organised social networks, particularly in Århus and Copenhagen, has resulted in a political mobilisation of migrants (see Togeby 2008). Even though the Finnish electoral system shares many features with the Danish one, ${ }^{19}$ the political mobilisation of migrants has remained low as immigration and integration issues have generally had low saliency on the political agenda in Finland and the number of candidates with a migrant background has remained low.

\subsection{Conclusions}

In this chapter different types of social involvement and their impact on electoral participation were tested. The empirical findings indicate that social capital, measured as the degree of organisational participation, at least partly explains electoral participation among immigrants in Finland, irrespective of other personal resources.

The results indicate that organisational participation essentially forms a social resource which has a positive effect on electoral participation. The analysis also shows that immigrant organisations form an asset for electoral participation. The results seem to support claims that ethnic organisations function as a gateway into the majority society instead of isolating migrants. The empirical material suggests that migrants that are involved in ethnic organisation activities both become involved in the social activities within the greater society and to a higher degree participate in political activities. Based on the findings it also seems sensible to conclude that it is important to support policies designed to lower the barriers for migrants to participate in organisational activities. Further research is however needed on how and why social participation affects political participation. This raises more interesting questions on

19 It is even more person centred than the Danish one. 
how these procedures work and if there are differences between different types of organisations.

Aside from organisational involvement, citizenship comes out as the most decisive predictor of electoral participation. Citizenship provides people with full political rights and makes the state of residence permanent, which according to earlier studies significantly increases the odds for participation in all types of societal activities. This also raises a question of how citizenship policies may act as a barrier for political integration and participation. In Finland citizenship policies are rather strict from a comparative perspective, which may have a negative impact on the political integration of migrants, as it may take almost a decade of permanent residence in the country before acquiring full civic rights.

Other variables which show a statistically significant relationship with electoral participation include the time of residence in Finland, gender and education. Gender differences may reflect the fact that politics in some cultures are dominated by males, making the political integration of women an issue one should direct special attention to. Education on the other hand strengthens the skills and abilities to follow and engage in political activities. One could thus raise the question, of whether education in societal matters should be more strongly incorporated into the agenda of the integration courses that are offered to immigrants.

Even though legislation and the rules for participation form an important aspect of the process, the results indicate that civil society organisations and political parties play a vital role for political mobilisation. Even though Denmark scores lowest on the integration scores on the MIPEX index (i.e. has the most unfavourable environment for participation) it seems that the Danish individual centred electoral system, the fairly high number of migrant candidates as well as well organised migrant groups, has resulted in a political mobilisation of migrants in Denmark. Finland on the other hand, seems to score fairly well on systemic features, but the short migration history in connection to the recent establishment of migrant organisations and the fact the political parties have not yet put much effort into mobilising migrants and nominating migrant candidates, seem to affect the political participation of migrants. Migration and integration issues have only in recent years become a central topic on the political agenda in Finland. A high degree of unemployment and discrimination of some migrant groups may also play a role.

\section{References}

Ahokas, L. 2010. Promoting immigrants' democratic participation and integration. Tampereen yliopistopaino, Juvenes Print: Tampere.

Andersen, K. and E.F. Cohen. 2005. Political Institutions and Incorporation of Immigrants. In: Wolbrecht and Hero (ed.) The politics of Democratic Inclusion. Temple University Press: Philadelphia. 
Barnes, S. and Kaase, M. 1979. Political Action: Mass Participation in Five Western Democracies. Beverly Hills, CA: Sage Publications.

Berger, M. Galonska, C. and R. Koopmans. 2004. "Political Integration by a Detour? Ethnic Communities and Social Capital of Migrants in Berlin." Journal of Ethnic and Migration Studies. 30(3): 491-507.

Bengtsson, B. 2004. Föreningsliv, makt och integration - ett inledande perspektiv. I: föreningslivet. I: Föreningsliv, makt och integration - Rapport från Integrationspolitiska maktutredningens forskningsprogram. Elanders Gotab: Stockholm.

Benito, M. 2005. Active civic participation of immigrants in Sweden. Country report prepared for the European research project POLITIS. Oldenburg 2005.

Borevi; K. 2004. Den svenska diskursen om staten, integrationen och föreningslivet. I: Föreningsliv, makt och integration - Rapport från Integrationspolitiska maktutredningens forskningsprogram. Elanders Gotab: Stockholm.

Dahl, R.A. 2000. On Democracy. New Haven, CT: Yale University Press.

van der Eijk, C. 2000. "Why Some People Vote and Others Do Not. In: Citizens Participation in European Politics. SOU 1991:151. Elanders Gotab: Stockholm.

Dahlstedt, M. and Herzberg, F. 2005. Strukturell diskrminering och politiskt deltagande. Inledande tankegångar. I: Dahlstedt, M. and F. Herzberg (red.) Demokrati på svenska. Om strukturell diskriminering och politiskt deltagande. SOU:112. Elanders Gotab: Stockholm.

Dalton, R.J. 1996. Citizen Politics: Public Opinion and Political Parties in Advanced Industrial Democracies. Second Edition. New Brunswick, NJ: Chatham House Publishers.

Dalton, R.J, McAllister, J. and M. Wattenberg 2002. "Political Parties and Their Publics. In: Luther, K.R. and Muller-Rommel, F. (ed.) Political Parties in the New Europe. Oxford University Press.

Demokratiapolitiikan suuntaviivat. Oikeusministeriö mietintöjä ja lausuntoja 2010:14.

van der Eijk, C. 2000. “Why Some People Vote and Others Do Not. In: Citizens Participation in European Politics. SOU 1991:151. Elanders Gotab: Stockholm.

Fahmy, E. 2003. Youth, Social Capital and Civic Engagement in Britain. Evidence from the 2000-01 General Household Survey. ESRC/ODPM Postgraduate Research Programme Working Paper 4, 2004.

Fennema, M. and J. Tillie 1999. Political Participation and Political Trust in a Multicultural Democracy. Civic Communities and Ethnic Networks in Amsterdam. Paper presented at the ECPR Joint Session of Work Shops. 2001. "Civic Community, Political Participation and Political Trust of Ethnic Groups." In: Behr, H. and S. Schmidt (Hrsg.) Multikulturelle Demokratien im Vergleich. Institutionen als Regulativ kultureller Vielfalt. Westdeutscher Verlag: Wiesbaden. pp. 199-217.

Forsander, A. 2004. "Social Capital in the Context of Immigration and Diversity: Economic Participation in the Nordic Welfare States." JIMI/RIMI, 5(2):207-227.

Giugni, M. and F. Passy. 2004. "Migrant Mobilization between Political Institutions and Citizenship Regimes: A Comparison of France and Switzerland." European Journal of Political Research 43: 51-82.

Hammar, T. 1979. Det första invandrarvalet. Stockholm: Publica.

Harinen, P. 2005. Mitähän tekis? Monikulttuuriset nuoret, vapaa-aika ja kansalaistoimintaan osallistuminen - tutkimushankkeen väliraportti. Nuorisotutkimusverkosto / Nuorisotutkimusseura, verkkojulkaisusarja.

Holmberg, S. 1981. Den svenska väljaren. /Uddevalla: Bohusläningen.

Ireland, P. 1994. Policy Challenge of Ethnic Diversity: Immigrant Politics in France and Switzerland. Cambridge, MA: Harvard University Press.

Jacobs, D. and J. Tillie. 2004. "Introduction: Social Capital and Political Integration of Migrants." Journal of Ethnic and Migration Studies, 30(3): 401-410. 
Koopmans, R. 2004. "Migrants Mobilisation and Political Opportunities: Variation among German Cities and a Comparison with the United Kingdom and the Netherlands." Journal of Ethnic and Migration Studies, 30(3): 449-470.

Lane, J-E and S. Ersson. 1990. "Macro and Micro Understanding in Political Science: What Explains Electoral Participation?" European Journal of Political Research, 18(4): 457-465.

Lundåsen, S. 2004. En föreningsbaserad demokrati? : ideella föreningar och valdeltagande i Sveriges kommuner under 1990-talet. Åbo Akademis tryckeri: Åbo.

Lepola, 0. 2004. “Does Immigration Challenge the Finnish Nation?” Pp. 268-288 inl Castrén, A-M., Lonkila, M. and M. Peltonen (eds.), In Between Sociology and History. Helsinki: Suomalaisen kirjallisuuden seura.

Melve, J. 2003. Innvandrerorganisasjoner i Norge. In. Mikkelsen, F. (ed.) Invandrerorganisationer i Danmark. In: Mikkelsen, F. (ed.) Invandrerorganisationer i norden. Phonix Trykkeriet: Århus. pp. 11-24

Mickelsson, R. (ed.). 2009. Puolueiden tulevaisuus. Oikuesministeriön julkaisuja: 6.

Mikkelsen, F. 2003. Invandrerorganisationer i Danmark. In: Mikkelsen, F. (ed.) Invandrerorganisationer i norden. Phonix Trykkeriet: Århus.

Milbrath, L.W. and M.L. Goel. 1977. Political Participation: How and Why Do People Get Involved in Politics? Second Edition. Chicago: Rand Mc Nally College Publishing Company.

Myrberg, G. 2004. Föreningsliv och politiskt deltagande. In: Bengtsson, B (ed.). Föreningsliv, makt och integration. Uppsala univeristet. pp.197-226.

Niessen, J., Huddleston, T. and L. Citron. 2007. Migrant Integration Policy Index. British Council, Migration Policy Group: Brussels.

Niemelä, S. 2007. Kansanvallan elvytys. Kiistakirjoitus demokratiapolitiikasta. Kansanvalistusseura. Dark: Helsinki.

Norris, Pippa 2002. Democratic Phoenix - Reinventing Political Activism. Cambridge: Cambridge University Press.

Putnam, R. 1993 Making Democracy Work: Civic Traditions in Modern Italy. Princeton, NJ: Princeton University Press. . 2000. Bowling Alone: The Collapse and Revival of American Community. New York: Simon and Schuster.

Rothstein, B. and D. Stolle. 2003. "Introduction. Social Capital in Scandinavia." Scandinavian Political Studies, 26(1): 1-26.

Saksela, S. 2003. Mångkulturella organisationer och invandrarorganisationer i Finland. In: Mikkelsen, F. (ed.) (2003) Invandrerorganisationer i norden. Phonix Trykkeriet: Århus. pp. 235-275.

Saukkonen, P. 2007. Politiikka monikulttuurisessa yhteiskunnassa. Helsinki: WSOY.

Siisäinen, M. and T. Kankainen. 2009. Järjestötoiminnan kehitys ja tulevaisuudennäkymät. Teoksessa: Katsaus suomalaisen kansalaisvaikuttamisen tilaan ja tulevaisuuteen. Oikeusministeriön julkaisuja (in print).

Tarrow, S. 1988. "National Politics and Collective Action: Recent Theory and Research in Western Europe and the United States." Annual Review of Sociology, 14: 421-440.

Teorell, J. 2003. "Linking Social Capital to Political Participation: Voluntary Associations and Networks of Recruitment in Sweden." Scandinavian Political Studies, 26(1): 243-258.

Tillie, J. 2004. "Social Capital of Organisations and Their Members: Explaining the Political Integration of Immigrants in Amsterdam." Journal of Ethnic and Migration Studies, 30(3): 529-541.

de Tocqueville, A. 2000. Democracy in America. New York: Bantham Books.

Togeby, L. 1999. "Migrants at the Polls: An Analysis of Immigrant and Refugee Participation in Danish Local Elections." Journal of Ethnic and Migration Studies, 25(4): 665-684. 
2004. "It Depends... How Organisational Participation Affects Political Participation and Social Trust Among Second-Generation Immigrants in Denmark." Journal of Ethnic and Migration Studies, 30(3): 509-528.

. 2008. "The Political Representation of Ethnic Minorities: Denmark as Deviant Case." Party Politics, 14(4): 325-343.

Triandafyllidou, A. and R. Groupas. 2007. European Immigration. A Sourcebook. Hampshire: Ashgate.

Uslaner, E.M. and R.S. Conley. 2003. "Civic Engagement and Particularized Trust: The Ties that Bind People to Their Ethnic Communities." American Politics Research, 31(4): 331-360.

Valtonen, K. 1999. "The Societal Participation of Vietnamese Refugees: Case Studies in Finland and Canada." Journal of Ethnic and Migration Studies, 25(3): 469-491.

Verba, S and N.H. Nie. 1981 [1972]. Participation in America. Political Democracy and Social Equality. New York: Harper and Row.

Verba, S., N.H. Nie and J-O Kim. 1978. Participation and Political Equality. A Seven-Nation Comparison. Cambridge: Cambridge University Press.

Vogel, D. and R. Groupas. 2006. POLITIS - Building Europe with New Citizens? An Inquiry into the Civic Participation of Naturalised Citizens and Foreign Residents in 25 Countries. www.politis. org.

Wass, H. 2008. "Generations and Turnout: The Generational Effect in Electoral Participation in Finland." Acta Politica, 35. Helsinki University Press.

Wass, H. and N. Wilhelmsson. 2009. Äänestysaktiivisuus Suomessa - raportti vaaliosallistumisen tutkimisesta, äänestysaktiivisuuden trendeistä ja osallistumistutkimuksen kehitystarpeista. Teoksessa: Katsaus suomalaisen kansalaisvaikuttamisen tilaan ja tulevaisuuteen. Oikeusministeriön julkaisuja 2009:5.

Weide, M. 2008. Maahamuuttajataustaiten kunnallispoliitikkojen ja kunnallisvaaliehdokkaiden poliittinen identiteetti Suomessa. Helsingin yliopisto. Unpublished Masters thesis.

Wilhelmsson, N. 2008. Maahanmuuttajien äänestysaktiivisuus pääkaupunkiseudulla. Kvartti 3/2008. Helsingin kaupungin tietokeskus.

Ålund, A. and C-U. Schierup. 1991. Paradoxes of Multiculturalism. Aldershot: Avebury.

\section{Other sources:}

Association of Finnish local and regional authorities, www.kuntaliitto.fi

Infed Encyclopedia, www.infed.org/biblio/social_capital.htm

Migrant Integration Policy Index, www.mipex.org

Politis, www.politis.org

Statistics Finland, www.tilastokeskus.fi

Statistiska centralbyrån, www.scb.se 